\title{
Systemic teacher continuous professional development as support of teaching practice
}

\author{
Eva Trnova \\ Faculty of Education, Masaryk University, Brno, Czech Republic \\ For correspondence: trnova@ped.muni.cz
}

\begin{abstract}
The gap between the teachers' education and the teaching practice in school is a significant problem. This problem has many causes. Our experience and research have brought us to the conclusion that it is necessary to create systemic teacher continuous professional development (CPD). Teacher pre-service and in-service education with practical experience should be systematically linked. Teachers' professional competences are finally formed through the combination of these three core parts of CPD. The outputs of our design-based research confirm this fact. We propose using the natural binding of three core parts of CPD and linking them systematically. We have found a set of current specific teachers' competences that need to be addressed in science and mathematics education. These include in particular: education of gifted students, implementation of connectivism and IBSME etc. These competencies can be sufficiently established only within systemic CPD. In our study we present some specific examples of these competences.
\end{abstract}

Keywords: systemic $\mathrm{CPD}$, teacher competences, teaching practice.

\section{Introduction}

The quality of education is closely related to the quality of teachers, which since the mid twentieth century has been at the centre of educational attention worldwide. Many research studies have shown that the quality of teachers is one of the most important factors influencing the quality of school education and student performance (Darling-Hammond, 2000; Hanusek et al, 2005). The quality of teachers and improving the quality of their education are considered key tools of educational reforms and innovations in school activities (Coufalova et al, 2003).

Improving the quality of teachers has also become a political priority, as evidenced by the attention that is paid to this issue in international documents from organisations such as UNESCO and OECD. The European Parliament resolution (adopted September 23rd, 2008) emphasized that Member States must place greater emphasis on teacher education and must devote more resources to this area because of the analysis that raising the quality of teacher education leads to substantial gains in student outcomes. To improve the quality of education and strengthen lifelong learning throughout the European Union it is necessary to support continuous and coherent professional development for teachers throughout their careers. It was recommended that all teachers should have ample opportunity to improve and update their knowledge, skills and competences (EU, 2008).

Similarly, the USA is also focussing on the quality of education. Science education experts and groups representing business and industry recognize on the basis of the contemporary situation that the main goal of education is to give students skills that they will need to prosper in a time of unprecedented global economic competition. There is overall agreement that the USA needs a workforce with generally higher levels of science and technology literacy for all students, as well as a sufficient number of highly gifted individuals entering scientific and engineering careers (Bybee and Fuchs, 2006). There are many reports about changes in education which have identified a number of findings and recommendations. The main goal, common to all reports, is the preparation of a "21st century workforce". These reports identified components at the core of science and technology education: 
teachers and teaching, contents and curricula, tests and assessments etc. Not surprisingly the emphasis in every report is placed on the need for the quality teachers, which is related with a high quality of teacher education: pre-service, in-service and all continuous professional development (hereinafter CPD).

Research and experience show no educational innovation will be sustained unless systemic and ongoing CPD of teachers is provided to support changes required in instruction (Osborne and Dillon, 2008). Pajares (1992) states that teachers' conceptions and beliefs are a product of their experiences in education in the same way as students' are. Teachers' pedagogical content knowledge (Shulman, 1987) has a long-term and complex development, therefore it is necessary to start with the preparation of teachers in pre-service education and continue in an in-service period of systemic CPD based on practical experience.

\section{Rationale}

Teachers' beliefs are an important factor that must be taken into account in teacher education. They are usually based on their experience of their own school attendance. Findings of many studies (Lederman, 1999; Powers et al, 2006; Raymond, 1997; Richardson, 1998) substantiate the relationship between teachers' beliefs and their classroom practices. Therefore it is often necessary during teacher education to remove false beliefs and replace them with research-based ones. Research shows that there is inertia with regard to teachers' beliefs. Findings indicate that teachers' beliefs and practice were not wholly consistent. Rather, teachers' practice was more closely related to their beliefs about subject content than to their beliefs about subject pedagogy. Teachers' beliefs about the subject content were highly influenced by their own experiences as a student and their beliefs about the subject pedagogy were primarily influenced by their own teaching practice.

However, the extent to which teacher preparation programmes influenced their beliefs or practice is limited. Teachers must be not only theoretically familiar with a method, but it is also necessary to try it out in classroom practice. Magoon (1977) talks about constructivism: teachers should build up their pedagogical knowledge and skills similarly to students, using their own experience from classroom practice and thus connecting pedagogical theory and practice. According to Korthagen et al (2001) in teacher education there is often a gap between theory and classroom practices that needs to be removed. He also recommends a constructivist approach in teacher education. This approach could help to remove the inertia of the teachers' false pedagogical beliefs.

According to Raymond (1997), teachers were monitored for four years, to see whether they implemented innovative teaching methods, which they acquired in teacher training, into classroom practice. Most of them reduced the frequency of implementation of these new methods with each passing year, and returned to those ones used before teacher training (Duffy and Roehler, 1986; Fullan, 1991). It focuses on the failure of teachers to adopt teaching activities, practices, and curricula that are suggested or mandated by those who are external to the setting in which the teaching is taking place: administrators, policy-makers, and staff developers. This view of change in teaching practice is explained by Morimoto (1973): "When change is advocated or demanded by another person, we feel threatened, defensive, and perhaps rushed. We are then without the freedom and the time to understand and to affirm the new learning as something desirable, and as something of our own choosing. Pressure to change, without an opportunity for exploration and choice, seldom results in experiences of joy and excitement in learning" (p. 255).

Many of the teacher training programmes are relatively short with only a few hours of workshops, and limited follow-up activities. Such training programmes have a chance of succeeding with those teachers whose beliefs match the assumptions inherent in the innovation; although even these teachers might not try out the innovation. It is estimated that such teacher education garners an implementation level of only 15 percent (Meyer, 1988). On the other hand, not all teacher training models result in such limited change. A substantial body of research has identified characteristics of reasonably successful training models. These qualities have been summarized by many (e.g., Griffin, 1986) and include the following: 
- The training process should be school-wide and context-specific

- Principals (or programme directors) should be supportive of the process and encouraging of change

- The training should be long term, with adequate support and follow up

- The training process should encourage collegiality

- The training content should incorporate current knowledge obtained through well-designed research

- The process should include adequate funds for materials, outside speakers, and substitute teachers to allow teachers to observe each other.

Another important factor that can help change teachers' beliefs is teamwork in education. According to Richardson (1998) teachers in discussions with colleagues more easily change their attitudes towards their own beliefs.

The complexity and diversity of teacher education led us to the conclusion that it is necessary to implement systemic and dynamic teacher education. This systemic CPD will be further studied in detail.

\section{Research question and methods}

Our main research issue is to determine the form and function of systemic CPD for science and mathematics teachers including school practice. In different countries a number of CPD models are implemented, but often without systemic structure. The dynamics of CPD is also important, as it will enable implementation of the latest research discoveries. Our research question is therefore as follows:

Is it necessary to develop and implement systemic CPD as a support of science and mathematics teachers?

We used a research method design-based research (hereinafter DBR), which is an important research method in science and mathematics education (Reeves, 2006). DBR as a development research method can be described as a cycle: analysis of a practical problem, development of solutions, evaluation and testing of solutions in practice, reflection and production of new design principles.

\section{Results and discussion}

The result of our research using the DBR starts with a simple chart of three basic parts of systemic CPD for teachers (see Fig 1).

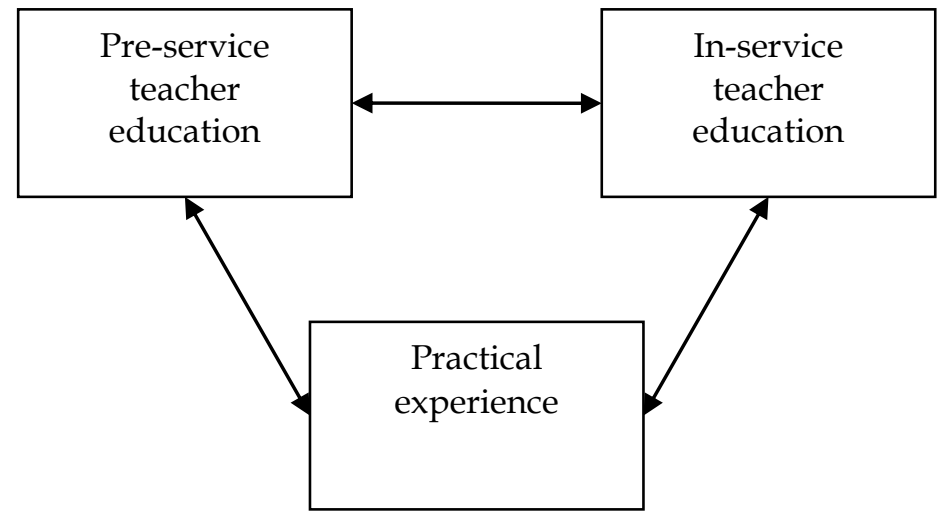

Figure 1. Chart of systemic CPD for teachers

The basis of systemic CPD is to connect all the three basic components: pre-service teacher education, in-service teacher education and practical experience. The research problem lies in a detailed analysis 
of all links between the elements of this three-component system. Our research is at the beginning of this process.

We applied DBR method in four steps:

(a) analysis of practical problems: education of gifted students in science and mathematics, connectivism in science education; implementation of these components in CPD for science teachers

(b) development of solutions: construction of science and mathematics teacher training courses

(c) evaluation and testing of solutions in practice: conducting CPD courses for science and mathematics teachers

(d) reflection on and production of new design principles: confirmation of the need to create systemic CPD for science and mathematics teachers.

This study presents the outcomes of our pilot research in which we have chosen three very important current components of CPD for science and mathematics teachers. These components are: education of gifted students in science and mathematics, connectivism in science education and inquiry-based science education and mathematics, hereinafter IBSME. These three components were analyzed in detail in terms of their inclusion in science teacher education (see bellow).

\section{Education of gifted students in science and mathematics.}

The support of gifted students in science and mathematics is an important part of education. The preparation of suitable conditions for the development of science and mathematics giftedness is an important task for teachers (Skrabankova, 2011). It involves the identification of giftedness and the development of students' giftedness. Teachers have to respond to special behaviours of gifted students:

- Students are not satisfied with passive memorizing, they ask more questions

- Students are curious and have unusual ideas

- Students are independent and often prefer working on their own

- Students come up with new solutions

- Students are creative

Our research resulted in the identification of specific educational needs of students gifted in science. In the year 2011, we distributed a questionnaire with a representative sample of 15 students aged 1518 from upper secondary schools who are gifted in science (Trnova and Trna, 2012b). We present (see Tab. 1) a part of the questionnaire results: a list of specific educational needs of gifted students indicated by more than $50 \%$ of them.

Table 1. Specific educational needs of students gifted in science.

\begin{tabular}{l}
\hline Experimentation \\
Measurement \\
Identifying the fundamental processes in nature \\
Observation \\
Analyzing phenomena \\
Expressing an opinion and defending it \\
Solving problems \\
Substantiation of solutions \\
Formulating conclusions \\
Describing phenomena \\
Verification of hypotheses \\
Data processing \\
Creating hypotheses \\
Evaluation
\end{tabular}


Experimentation, analyzing of phenomena and solving problems have an important role in the science education of gifted students. Teacher training courses should be focused on these special educational needs of gifted students.

Connectivism in science education.

Fast ICT development strongly influences education. D. Oblinger and J. Oblinger (2005) describe today's students as the Net Generation. Characteristics of the Net Generation are:

- Students are visually literate, but their text literacy is not developed enough.

- Students intuitively use a variety of ICT without an instruction manual.

- Students prefer speed to accuracy.

- Students multitask.

- Students prefer to learn by doing rather than by being told what to do.

- Students learn well through inquiry by themselves or with their peers.

- Students prefer to learn and work in teams (a peer-to-peer approach - help each other).

Findings about the Net Generation have resulted in a new pedagogical theory of connectivism as "a learning theory for the digital age". G. Siemens (2005) as its founder states that learning is a network phenomenon, influenced by socialization and technology. He established the set of principles of connectivism (Siemens, 2005, p.5):

- Learning and knowledge rests in diversity of opinions

- Learning is a process of connecting specialized nodes or information sources

- Learning may reside in non-human appliances

- Capacity to know more is more critical than what is currently known

- Nurturing and maintaining connections is needed to facilitate continual learning

- Ability to see connections between fields, ideas, and concepts is a core skill

- Currency (accurate, up-to-date knowledge) is the intent of all connectivistic learning activities

- Decision-making itself is a learning process. Connectivism is nowadays widely discussed (Downes, 2012) and its influences tested on science education.

Our research (Trnova and Trna, 2012a, and 2012b) is mainly focused on studying possible connectivist influences in science education: identification of connectivist factors in science education and development of connectivist educational methods. We have discovered the first set of connectivist factors:

- Sharing and acquisition of new science knowledge and skills

- Exchange of experience among students and also among teachers

- Creation of learning/teaching network structures

- Development of communication competencies of students and teachers

- Development of cooperation competencies of students and teachers

- Motivation of students and teachers by communication and cooperation with colleagues, use of ICT, etc.

- Teachers' and students' improvement of skills in using ICT and English

This new connectivist approach necessarily has to be implemented in CPD of science teachers. Science teachers need to be equipped with new competences and innovated professional skills based on connectivism (Trna and Trnova, 2010, and 2012). To strengthen connectivist teacher education we used connectivist methods also in their training. These teacher training methods include:

- Teamwork of trained teachers

- Networking by creation of information and cooperative ties among members of a team of trained teachers

- Various use of ICT

Inclusion of connectivism in systemic CPD is an absolute priority.

IBSME.

In many countries, including the Czech Republic, school science education puts emphasis primarily on traditional transmissive teaching methods. It is necessary to revise educational content and apply 
appropriate modern teaching/learning methods such as IBSME, which is an instructional learnercentred approach. Students solve problems independently and competently, conduct self-directed learning and work in teams, etc. Teachers sometimes struggle in designing and implementing IBSME. Improper application of IBSME may not produce the expected positive results and the disappointed teacher goes back to the traditional style of teaching (Darling-Hammond et al, 2008). It is essential to acquire the professional competency to apply IBSME, and this involves a set of specific skills: to be able to determine what level of IBSE can be used, to be able to choose the content and to transform it pedagogically into IBSME. It is essential to integrate these competences to apply IBSME in CPD for science and mathematics teachers.

We discovered the five stages of acquisition in the development of teacher's skills to apply IBSME:

(a) Motivation stage: Development of professional interest and attitudes towards IBSME.

(b) Orientation stage: Acquiring knowledge necessary for IBSME.

(c) Stabilization stage: Solving simple applied tasks of IBSME application.

(d) Completing stage: Solving complicated applied tasks of IBSME application.

(e) Integration stage: Solving teaching problem situations in school practice (new skill is integrated into skill structure).

The completion and integration stages are conditioned by several years of experience of the teacher. This is the reason why it is not possible to finish acquiring competence for implementation of IBSME only in pre-service teacher training. Teacher education in IBSME is a long-term process. By use of DBR we have identified links between the above-mentioned stages of the development of skills to apply IBSME and levels of IBSME (see Table 2).

Table 2. Model of development of skills for IBSME application.

\begin{tabular}{cccc}
\hline $\begin{array}{c}\text { Period of } \\
\text { teacher } \\
\text { training }\end{array}$ & $\begin{array}{c}\text { Acquiring stage of } \\
\text { teacher skills for } \\
\text { IBSME application }\end{array}$ & $\begin{array}{c}\text { Levels of IBSME with full } \\
\text { teacher competency to } \\
\text { implement }\end{array}$ & $\begin{array}{c}\text { Teacher educational } \\
\text { methods } \\
\text { (examples) }\end{array}$ \\
\hline Pre-service & $\begin{array}{c}\text { (a) Motivation stage } \\
\text { (b) Orientation stage }\end{array}$ & $\begin{array}{l}\text { (1) Confirmation } \\
\text { (2) Structured }\end{array}$ & $\begin{array}{l}\text { IBSME video analysis; the } \\
\text { first practical application of }\end{array}$ \\
& (c) Stabilization stage & & IBSME in school practice \\
\hline
\end{tabular}

\section{Practical teaching experience}

\begin{tabular}{llll}
\hline In-service & $\begin{array}{l}\text { (d) Completion stage } \\
\text { (e) Integration stage }\end{array}$ & $\begin{array}{l}\text { (3) Guided } \\
\text { (4) Open }\end{array}$ & Action research \\
\hline
\end{tabular}

To implement effective teacher training for IBSME it is necessary to compile a system of pedagogical professional teachers' knowledge, understandings and skills. We present the initial outputs of our DBR in the field of IBSME application:

- Knowledge and understanding of IBSME paradigms and objectives

- Knowledge and understanding of each IBSME level

- Skill to select appropriate contents (from everyday life etc.)

- Skill to transform the contents into individual IBSME levels

- Skill to motivate students (simple experimenting, projects)

- Skill to ask questions in accordance with IBSME

- Skill to conduct action research

- Skill to apply ICT in IBSME

- Skill to encourage students in communication skills in IBSME

- Skill to organize student educational activities in IBSME

- Skill to use a wide range of educational techniques (methods, forms, and aids) suitable for IBSME

Teacher education for IBSME integrates pre-service and in-service knowledge, understandings and skills based on experience from practice as a part of systemic CPD. 


\section{Conclusions}

We try to close the gap between the education of teachers and teaching in schools. Our proposed solution is the creation of systemic CPD for science and mathematics teachers. Its core is the connection of all the three basic components of CPD: pre-service teacher education, in-service teacher education and practical experience. It is necessary to do a detailed analysis of the links between the elements of this three-component system in future research.

We used as a research sample three current specific teachers' competences that need to be addressed in science and mathematics education: education of gifted students, implementation of connectivism and IBSME. Our pilot research confirmed our hypothesis that the three selected teachers' competencies can be sufficiently established only within systemic CPD. Insulating implementation would result in unnecessary repetition of the same knowledge and skills. A bigger problem is the lack of connections between pedagogical knowledge and skills into a coherent whole. The result of our research is a recommendation to create systemic CPD for science and mathematics teachers.

\section{Acknowledgements}

The study was initiated within the project the project PROFILES: Professional Reflection-Oriented Focus on Inquiry-based Learning and Education though Science (FP7-SCIENCE-IN-SOCIETY-2010-1, 266589).

\section{References}

Bybee, R. W., \& Fuchs, B. (2006). Preparing the 21st century workforce: A new reform in science and technology education. Journal of Research in Science Teaching, 43(4), 349-352.

Coufalova, J., Minhova, J. and Vankova, J. (2003). Restructuring of teacher training in order to improve its quality. In Quality Education in European Context and the Dakar Follow-up. (pp. 53-57). Nitra: Constantine the Philosopher University.

Darling-Hammond, L. (2000). Teacher Quality and Student Achievement. a Review of State Policy Evidence. Education Policy Analysis Archives.

Darling-Hammond, L., Barron, B., Pearson, P. D., Schoenfeld, A. H., Stage, E. K., Zimmerman, T. D., Cervetti, G. N. and Tilson, J. (2008). Powerful Learning: What We Know About Teaching for Understanding. San Francisco: John Wiley \& Sons Inc., by Jossey-Bass, a Wiley imprint. Edutopedia. (accessed January 2014)

Downes, S. (2012). Connectivism and Connective Knowledge. National Research Council. Canada. http:/ / www.downes.ca/files/Connective_Knowledge-19May2012.pdf (accessed January 2014)

Duffy, G. and Roehler, L. (1986). "Constraints on teacher change." Journal of Teacher Education, 35, 55-58.

EU(2008). http://www.europarl.europa.eu/search/highlight.do?hitLocation=http://www.europarl.europa.eu/sides/getDoc .do\%3Ftype\%3DREPORT\%26reference\%3DA6-2008-0304\%26format\%33DXML\%26language\%3DCS (accessed January 2014)

Fullan, M. G. (1991). The New Meaning of Educational Change. New York: Teachers College Press.

Griffin, G. (1986). "Clinical teacher education." In J. Hoffman \& S. Edwards (eds.), Reality and Reform in Clinical Teacher Education (pp. 1-24). New York: Random House.

Hanusek, A. E., Kain, F. J., Rivkin, G. S. (2005). Teachers, Schools, and Academic Achievement. Econometrica, 2, 417-458.

Korthagen, F. A. J., Kessels, J., Koster, B., Lagerwerf, B. and Wubbels, T. (2001). Linking practice and theory: The pedagogy of realistic teacher education. Routledge.

Lederman, N. G. (1999). Teachers' understanding of the nature of science and classroom practice: Factors that facilitate or impede the relationship. Journal of research in science teaching, 36(8), 916-929.

Magoon, A. J. (1977). Constructivist approaches in educational research. Review of Educational Research, 47(4), 651-693.

Meyer, L. (1988). Research on implementation: What seems to work. In S. J. Samuels \& P. D. Pearson (eds.), Changing School Reading Programs (pp. 41-57). Newark, DE: International Reading Association.

Morimoto, K. (1973). Notes on the context for learning. Harvard Educational Review, 10(4), $245-257$.

Oblinger, D. and Oblinger J. (2005). Educating the Net Generation. EDUCAUSE. http:/ / www.educause.edu/educatingthenetgen/ (accessed January 2014)

Osborne, J. and Dillon, J., (2008). Science education in Europe: Critical reflections. London: Nuffield Foundation.

Pajares, M. F. (1992). Teachers beliefs and educational research: Cleaning up a messy construct. Review of Educational Research, 62(3), 307-332.

Powers, S. W., Zippay, C. and Butler, B. (2006). Investigating Connections Between Teacher Beliefs and Instructional Practices with Struggling Readers. Reading Horizons, 47(2).

Raymond, A. M. (1997). Inconsistency between a beginning elementary school teacher's mathematics beliefs and teaching practice. Journal for research in mathematics education, 550-576.

Reeves, T. C. (2006). Design research from the technology perspective. In J. V. Akker, K. Gravemeijer, S. McKenney, \& N. Nieveen (Eds.), Educational design research. (pp. 86-109). London, UK: Routledge.

Richardson, V. (1998). How teachers change. Focus on Basics, 2(C), 1-10.

Shulman, L. S. (1987). Knowledge and Teaching: Foundations of the new reform. Harvard Educational Review, 57, 1-22. 
Siemens, G. (2005). Connectivism: A Learning Theory for the Digital Age. Elearnspace.

http:/ / www.elearnspace.org/Articles/connectivism.htm (accessed January 2014)

Skrabankova, J. (2011). The Factors of the Development of Cognitive Processes of Gifted Pupils in the Constructivist Framework. The new educational review, 26(4), 219-227.

Trna, J. (2013). How to educate and train science teachers in IBSE experimentation. . Proceedings of conference IMSCI 2013. The 7th International Multi-Conference on Society, Cybernetics and Informatics. Orlando, USA, International Institute of Informatics and Systemics. 176-180.

Trna, J. (2012). How to motivate science teachers to use science experiments. Journal of Systemics, Cybernetics and Informatics, 10(5), 33-35.

Trna, J. and Trnova, E. (2010). ICT-based collaborative action research in science education. Proceedings of conference IMSCI'10. The 4th International Multi-Conference on Society, Cybernetics and Informatics. Volume I. Orlando, USA. International Institute of Informatics and Systematics. 68-70.

Trna, J. and Trnova, E. (2012). Inquiry-Based Science Education in Science and Technology Education as a Connectivist Method. Proceedings of the 8th International Conference on Education. Samos, Greece. Research and Training Institute of East Aegean. 831-837.

Trnova, E. and Trna, J. (2012a). Connectivism in Science and Technology Education with Emphasis on International Cooperation. Journal of Social Sciences, 8(4), 490-496.

Trnova, E. and Trna, J. (2012b). Influence of connectivism on science education with emphasis on experiments. In Bruguiere, C., Tiberghien, A. \& Clément, P., (co-ed. Marzin, P. \& Lavonen, J.). E-book proceedings of the ESERA 2011 conference: Science Learning and Citizenship. Part 4. Lyon, France. European Science Education Research Association. 83-89. 